nik za razvoj u prostoru. Razvoj se sužavao na sve uži prostor, što je razlogom »neprekinute proizvodnje viška stanovništva«. Prema tome, riječ je o tipu društva u kojem su modernizacijski procesi neprekinuto nagrizali biološku supstancu. Budući da je svaka modernizacija »odbacivala « najvitalnije, a od 1991. u prosjeku i obrazovanije stanovništvo, postavlja se logično pitanje zašto je to tako. Upravo stoga autori tu pojavu stavljaju u širi društveni kontekst, kroz dugo vrijeme i, što je posebno bitno, koriste se novim metodologijskim pristupom. Politički su se akteri mijenjali, a odselidba je konstanta. Kvantitativnu su stranu istraživali demografi i demografskoj struci bliski, malobrojni, istraživači opće i gospodarske povijesti, ali je dosada izostao cjelovit i sustavan sociologijski pristup: bio je tek mar- ginalan. Zato se tijekom vremena pri tumačenju razmatrane problematike oblikovao, ponavljao i tako ustalio stereotipni metodološki pristup »odseljeničkom pitanju«. Tematizirana analiza u ovom djelu snažan je otklon od ustaljenoga pristupa, jednodimenzionalnog i uskog. Istovremeno je ova studija paradigma kako zanimljivo i s mnoštvom skladno ugrađenih činjenica utvrditi bitne značajke modernizacijskih procesa s ciljem razjašnjavanja kontinuiteta odselidbe iz Hrvatske, ali i odnosa hrvatskog društva prema odseljenicima. Jednostavno i sažeto: studija je analitičkim pristupom i razradom teme nadasve izvrsno i originalno znanstveno djelo.

Anđelko Akrap Ekonomski fakultet Sveučilišta u Zagrebu, Zagreb
Marko Rimac, Goran Mladineo

\section{Zadarsko okružje na mletačkom katastru iz 1709. godine, Dio II: Srednji kotar}

Zadar: Državni arhiv u Zadru, 2011, 240 str.

DOI: 10.11567/met.29.1.7

Autori knjige, hrvatski povjesničari mlađe generacije Marko Rimac i Goran Mladineo sustavno su izdvojili i kritički priredili dio opsežnog fonda originalnih dokumenata i karata mletačkoga katastra iz 1709. koji je pohranjen u Državnom arhivu u Zadru pod nazivom Mletački katastri Dalmacije 17. i 18. stoljeća. Katastar obuhvaća zadarsko područje kao okružje (Contado di
Zara) koje je bilo ustrojeno na području Donjega, Srednjega i Gornjega kotara u okviru mletačkih krajina prema Osmanskom Carstvu. U ovoj su knjizi objavljeni popisi i karte Srednjega kotara (Contado Medio), dok su materijale vezane uz Donji kotar autori objavili u prethodnom svesku, koji je izašao 2009. Građa za Gornji kotar bit će sastavni dio treće knjige istoimene trilogije. Bogatstvo sačuvanih izvora, uz profesionalni interes, ali i osobnu znatiželju proisteklu iz regionalne bliskosti, potaknulo je istraživače, prije svega zainteresirane za povijest rodova, da uz tehničku i stručnu podršku Zadarskog arhiva objave dio o zadarskome povijesnom prostoru rano- 
ga novog vijeka. Osim toga izazov im je predstavljao i skroman opseg dosad objavljenih dokumenta o tom prostoru, o kojem ima malo monografija, pa čak i sustavnije stručne literature. U tom je kontekstu katastar još vredniji jer je temeljen na terenskome radu, pa bilježi stvarno stanje i promjene na mletačkoj Novoj stečevini nakon nekoliko vrlo burnih stoljeća sukoba na mletačko-osmanskoj granici. $\mathrm{Na}$ dalmatinskim rubovima različitih carstava preklapali su se višestruki interesi, ali i demonstrirala moć i politika elita. Po odlasku Osmanlija iz zaleđa dalmatinskih gradova Venecija je nastojala što prije »regulirati« područja koja je stekla mirovnim sporazumima i iskoristiti značajne (i)migracijske valove. Stoga su po okončanju Morejskoga rata prionuli na izradu katastra, nastojeći zadržati novonaseljeno stanovništvo - bivše osmanske podanike (Morlake) te im uz određene porezne povlastice osigurati egzistencijalno neophodan zemljišni minimum. Primarni cilj bio je stabilizacija mletačkoga vojnog ustroja organiziranjem osvojenog teritorija i novodoseljenog stanovništva u banderije, specifični oblik vojnog oblikovanja mletačkih krajina temeljen na obvezi vojne službe. Upravo je u detektiranju i valorizaciji takve politike procjena katastra i katastarske čestice kao mjerne jedinice za ocjenu kvalitete svakodnevnog života iznimno važna. Riječ je o prostoru koji je obuhvaćao petnaest onodobnih sela (i zaselaka) Srednjega kotara, organiziranih u banderije (barjake) na čelu s harambašama ili kapetanima. Činili su ih Grusi s Briševom, Murvica, Smoković, Zemunik, Škabrnja s Ambarom i Prkosom, Sukošan s Galovcem, Donje Biljane, Nadin, Ra- štević, Sopot, Perušić, Kolarina, Vukšić, Prović i Morpolača.

Knjiga je podijeljena na predgovor i šest poglavlja koja problemski propituju mogućnosti čitanja katastarskih izvora. Slijede zaključne napomene, prikazi karata te transkribirana arhivska građa spomenutih naselja, a na samome su kraju bibliografija, popis karata i bilješke o autorima.

Autori problematiziraju neke od ključnih fenomena dalmatinskoga pograničja u ranome novom vijeku na temelju njihove prostorne i političkostrateške kontekstualizacije. Terminološko objašnjavanje onovremene teritorijalizacije i pojmovlja nužno je za razumijevanje ne samo strukture već i ekonomske raspodjele moći, a time i distribucije ovlasti na mletačkom posjedu između »običnih Morlaka« i njihovih serdara. Koreliranjem mletačko-osmanskih ratova i nastanka višestrukih krajišta (mletačko-osmanskoga, mletačko-habsburškog i habsburško-osmanskog) u prvom poglavlju autori pružaju faktografski uvid u ključne prijelomnice u vojnome, ekonomskom i demografskom slabljenju Osmanlija, ali naznačuju i veliki mirnodopski razvojni potencijal privlačenja njihovih podanika na mletačko tlo.

Drugo se poglavlje bavi migracijama Morlaka u zadarsko zaleđe, posebno diskontinuitetom srednjovjekovnog stanovništva na tim prostorima, čija se pusta selišta naseljavaju doseljenicima iz dublje (ličke, bosanske i hercegovačke) unutrašnjosti. I dok je nakon Kandijskoga rata veliki broj katolika s toga područja preseljen na mletačko područje, njihovo mjesto nastanjuju većinom izbjegli pravoslavni Morlaci, a dolazi i do naknadnih višekratnih preseljavanja po Ravnim kota- 
rima i Bukovici. Kotari su demografski pretežito gubili stanovništvo, što je svakako imalo i ekonomskih posljedica, dok su Bukovica i Podgorje taj manjak nadomještavali novim doseljenicima, a dio je permanentnih kretanja tekao i na ustaljenim transhumantnim stočarskim rutama.

Vjerski odnosi odnosno promjene $\mathrm{u}$ etničkoj strukturi u središtu su sljedećeg poglavlja. Autori se kritički osvrću na dio postojeće literature i uspoređuju katastar s vizitacijama ninskoga i skradinskoga biskupa upućujući na opseg migracija.

Usporedba statističkih podataka iz katastra s prethodnima odnosno suvremenim srodnim dokumentima osnovna je tema četvrtog poglavlja. Komparacija sa sličnim materijalima u perspektivi ranonovovjekovnih procesa duga trajanja dijelom argumentira mletačko teritorijalno posezanje za posjedima u zaleđu, odnosno legitimira širenje suvereniteta na Novu stečevinu, a može poslužiti i pri rekonstrukciji fizičkih ili kulturnih ambijenata. Propituje se odnos numeričkih popisa i katastarskih karata, i to od antike do ranoga novog vijeka. U kontekstu ekonomskih inicijativa, ali i posjedovnih interesa, bilo privatnih, bilo državnih (fiskalnih i vojno-mobilizacijskih), katastar dokumentira i ekonomsku pokretljivost $\mathrm{u}$ krajiškim zajednicama, posebno za područja koja su u ratnim operacijama promijenila suverena. Katastarski popisi ujedno (i očekivano) otkrivaju velike ratne gubitke i nestanak čitavih obitelji, praćene daljnjim demografskim i migracijskim mijenama. Autori procjenjuju važnost katastra za mletačkog vlastodršca koji je u mogućnosti selektivno bilježiti promjene koje mu koriste, a druge zanemarivati. Katastar tako zanemaruje pitanja poput diobe zemljišta, parcelacije, selektivne investiture ili grananja obitelji, iako bi upravo ti podaci objasnili sliku o skrivenim interesima Venecije, primjerice onima ugrađenim $\mathrm{u}$ agrarne reforme.

$\mathrm{U}$ petom poglavlju autori na primjerima katastarske općine (banderije), koju čine sela Škabrnja, Ambar i Prkos, preispituju mogućnosti katastarskog izvora kao podatka za rekonstrukciju transformacije okoliša, izmjene toponimije i stanovništva odnosno raspršivanja posjeda u 18 . stoljeću, što, uz uobičajene ekonomske ili povijesne, bitno snaži mogućnost kulturnih i etničkih studija. Sve se karakteristične informacije mogu pratiti i na katastarskim kartama te komparativno analizirati u sinkronijskoj (s drugim više ili manje sličnim prostorima) ili anakronijskoj perspektivi, primjerice uspoređivati s austrijskom izmjerom i katastrom Dalmacije s početka 19. stoljeća. Na taj se način može rekonstruirati i dio starih osmanskih, pa i predosmanskih naselja, izgled kulturnoga i prirodnoga krajobraza, količinu i namjenu korištenog zemljišta, način obrade ili naseljenost, ali se mogu pratiti i razvojne promjene tijekom stoljeća.

Iduća dva poglavlja razmatraju kako se kroz udio pojedinih poljoprivrednih kultura i obradivoga tla reflektiraju agrarni odnosno širi ekonomski, ali posredno i demografski potencijali toga prostora, a spomenuti podaci ujedno omogućuju čak i analizu strukture obitelji. Zaključna tumačenja objašnjavaju kategorije teritorijalizacije te predstavljaju logiku sumarnoga katastika. 
Slijedi kratki povijesno-demografski uvod u analizu katastarske građe za svaku od spomenutih banderija, $\mathrm{s}$ tabličnim prikazima građe za konkretno naselje. Tablični podaci uključuju ukupni broj članova pojedine obitelji, a zabilježeni su ime i prezime kućnog starješine te ime njegova oca. U nastavku je popis imovine kućanstva, prije svega broj obradivih i neobradivih površina raspoloživog zemljišta u određenoj kategoriji, a potom zabilješke o vrsti stoke.

Katastar prikazuje zatečeno stanje na terenu 1709., koje se održalo jer nakon toga redistribucija zemlje nije provođena. Premda su mletački katastri izrađivani s ciljem ekonomskofiskalne konsolidacije mletačke vlasti i uspostave krajine prema Osmanskome Carstvu te su prije svega bilježili posjedovne odnose, oni postavljaju temelje za klasifikaciju kvalitete zemljišta (boniteta), pa u nekim slučajevima dovode i do djelomične melioracije tla. Popisom se regulirala trajnost osvojenih ili investiranih posjeda, ali uz njih se vezivalo novodošlo stanovništvo. Partikularni interesi ili nesustavna pravna praksa omogućili su i drugačiju podjelu od dva padovanska kampa zemlje po članu obitelji, posebno obiteljima zaslužnih serdara ili pak manje moćnima (udovice), koji su dobili manje od toga minimuma, što je produbljivalo imovinske razlike. Detaljne katastarske karte zadarskog okružja iz spomenutog fonda osim naseljima i važnijim fortifikacijama obiluju i oro-hidrografskim elementima, pedološkim i vegetacijskim podacima, uporabnom klasifikacijom tla i drugim komparativno važnim podacima za potpuniju ekohistorij- sku analizu jedinstvenih krajolika. Integrativnost i višeslojnost katastra kao povijesnoga vrela pružaju vrlo široki okvir za istraživanje, ali istovremeno daju odgovore i na neka usko specijalizirana pitanja, primjerice iz područja lokalne toponimije. Razlozi razmjerne stagnacije kopnene unutrašnjosti u odnosu na dalmatinsko priobalje u to doba tek dijelom leže u samim vojnim sukobima, a objavljena građa razotkriva ih i u posjedovnim, ekonomskim, demografskim, socijalnim i različitim drugim politikama Serenissime.

Katastarski izvori koje su nam autori predstavili i time učinili široko dostupnima u ovoj kritičkoj obradi arhivske građe, postavljajući visoke standarde interpretacije sličnih dokumenata, sigurno će zaintrigirati istraživače svakodnevice, kulturne ili socijalne povijesti, botanike, geomorfologije, arheologije, arhitekture, povijesti umjetnosti, ekonomije, povijesti okoliša, rodoslovlja, onomastike, demografije ili migracija, prije svega gledano iz mikroperspektive, posebno $u$ istraživanjima širega, interdisciplinarnoga karaktera. Pokazali su i da su katastarski fondovi prvorazredni izvori podataka za analizu u suvremenim diskurzivnim i metodološkim okvirima te da mogu odgovoriti na raznorodne zahtjeve pred kojima se istraživači nalaze.

\section{Dubravka Mlinarić}

Institut za migracije i narodnosti, Zagreb 